\title{
Non-deep physiological dormancy in seeds of Euphorbia jolkinii Boiss. native to Korea
}

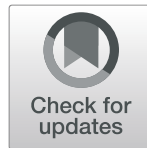

Hye Jin $\mathrm{Oh}^{1 \dagger}$, Un Seop Shin ${ }^{1,2+}$, Seung Youn Lee ${ }^{1,3 \dagger}$, Sang Yong Kim and Mi Jin Jeong ${ }^{1 *}$

\begin{abstract}
Background: Euphorbia jolkinii Boiss. is a perennial species native to Jeju Island and the southern coastal area of Korea. Particularly on Jeju Island, the yellow flowers of E. jolkinii Boiss. have a high ornamental value because of their contrast with basalt. This study was conducted to investigate the effects of different temperatures $(5,15,20$, and $\left.25^{\circ} \mathrm{C}\right)$ and gibberellic acid $\left(\mathrm{GA}_{3}\right)$ concentrations $(0,10,100$, or $1000 \mathrm{mg} / \mathrm{L})$ on seed dormancy and germination of E. jolkinii. In addition, we classified the seed dormancy type and compared types with those of other species in the same genus.

Results: The number of seeds with viable embryos and endosperms was approximately $66 \%$. The final germination percentages at $5,15,20$, and $25^{\circ} \mathrm{C}$ were $51.7 \%, 83.5 \%, 2.6 \%$, and $0.0 \%$, respectively. In $\mathrm{GA}_{3}$ concentration experiments, the final germination percentages of $0,10,100$, and $1000 \mathrm{mg} / \mathrm{L}$ were $83.5 \%, 91.7 \%, 79.1 \%$, and $83.4 \%$, respectively, at $15{ }^{\circ} \mathrm{C}$ conditions, and $0.0 \%, 6.9 \%, 13.2 \%$, and $27.3 \%$, respectively, at $25^{\circ} \mathrm{C}$.

Conclusions: Germination improved at temperatures of $15^{\circ} \mathrm{C}$ or lower. Furthermore, $\mathrm{GA}_{3}$ treatment effectively reduced germination times. Thus, the seeds of E. jolkinni were classified as having non-deep physiological dormancy.
\end{abstract}

Keywords: Germination temperature, Gibberellic acid, Native plant, New ornamental plants, Physiological dormancy

\section{Background}

Euphorbia jolkinii Boiss. is a perennial herbaceous plant belonging to the Euphorbiaceae family (KPNI 2019). This plant is mainly distributed along the coasts of Jeju, Jeonnam, and Gyeongnam in Korea (Steinmann and Porter 2002). The genus Euphorbia has 1000-1600 species worldwide and is mainly distributed in subtropical and temperate zones (Steinmann and Porter 2002). Plants of the genus Euphorbia produce poisonous sticky white sap when damaged, and their flower structure is unique; therefore, they are grown for ornamental purposes or used for landscape decoration (Euphorbia PBI 2012). There are approximately 19 species native to Korea, including E. jolkinii, E. esula L., E. helioscopia L.,

\footnotetext{
* Correspondence: mjjeong121@korea.kr

${ }^{\dagger}$ Hye Jin Oh, Un Seop Shin and Seung Youn Lee contributed equally to this work.

'Division of Plant Resources, Korea National Arboretum, Yangpyeong 12519, Korea

Full list of author information is available at the end of the article
}

and E. humifusa Willd. Ex Schltdl (Park 2007; KNA 2017). E. jolkinii grows to $40-80 \mathrm{~cm}$ in height and forms a colony with more than 30 stems per population (Bae 2000; Shin et al. 2018a).

The inflorescence is cyathium, consisting of a number of stamens and one pistil, and yellow-green flowers bloom from March to May. The fruit is a capsule, there are bumps on the surface, and the seeds are round and flat, approximately $3 \mathrm{~mm}$ in diameter. Stems with green leaves grow in winter, and flowering begins in early spring and lasts for 3 months. In particular, the colorful yellow-green flowers contrast with basalt and have a high ornamental value in the native habitat on Jeju Island.

With the enactment of the Nagoya Protocol, biodiversity and biogenetic resources are highly valued, and efforts are being made to develop and industrialize native plants (Oh et al. 2018). E. jolkinii is a medicinal plant material, and leaves and stems have been used as

(c) The Author(s). 2021 Open Access This article is licensed under a Creative Commons Attribution 4.0 International License, which permits use, sharing, adaptation, distribution and reproduction in any medium or format, as long as you give appropriate credit to the original author(s) and the source, provide a link to the Creative Commons licence, and indicate if changes were made. The images or other third party material in this article are included in the article's Creative Commons licence, unless indicated otherwise in a credit line to the material. If material is not included in the article's Creative Commons licence and your intended use is not permitted by statutory regulation or exceeds the permitted use, you will need to obtain permission directly from the copyright holder. To view a copy of this licence, visit http://creativecommons.org/licenses/by/4.0/. 
medicinal materials in oriental medicine. To verify and exploit these effects, studies on the pharmacological effects of extracts including their antioxidant and antibacterial activities, as well as melanin synthesis in melanoma cells have been conducted (Park et al. 2005; Kim et al. 2006; Kim et al. 2017). In addition, the unique, large flower structure and herbivorous form of E. jolkinii are considered to be of high ornamental value. To this end, researchers have evaluated the environment and growth characteristics of native habitats (Shin et al. 2018a), the vase life of cut flowers (Oh et al. 2018; Song et al. 2019a), cuttings for propagation (Shin et al. 2017), and cultivation according to pot size and nutrient conditions (Shin et al. 2018b). However, the dormancy characteristics of seeds and the conditions and characteristics of seed germination have not yet been reported.

Seed dormancy refers to the plant's self-suppression of germination under adverse environmental conditions for survival and is classified as physiological dormancy (PD), morphological dormancy (MD), morphophysiological dormancy (MPD), physical dormancy (PY), and combinational dormancy (PY + PD) (Baskin and Baskin 1998; Baskin and Baskin 2004; Fenner and Thompson 2005). In PD, dormancy is affected by cold stratification, after-ripening, and gibberellic acid (GA) treatment. PD can be divided into three types: non-deep PD, intermediate PD, and deep PD, depending on the depth of dormancy (Nikolaeva 1977; Baskin and Baskin 2014). Non-deep PD is the most common form of seed dormancy. This type of dormancy can be broken by short periods of chilling stratification, after-ripening (dry storage), or gibberellin treatment. Intermediate $\mathrm{PD}$ usually requires at least 2 months of chilling or gibberellin application as a substitute for chilling, whereas deep PD requires a long period of at least 3 months of chilling stratification to relieve dormancy and generally does not respond to exogenous gibberellin application (Geneve 2003; Baskin and Baskin 2004). MD and MPD are ecophysiological characteristics that occur because seeds have immature embryos at the time they are separated from the parent plant (Adams et al. 2005a, 2005b). Immature embryos are defined not by the size of the embryo, but by how much the embryo must still grow before germination (or before the seed coat is split) (Baskin and Baskin 2005; Chen et al. 2015). Seeds in the genus Euphorbia have been reported to be mostly nondormant or to show PD (Best et al. 1980; Sen and Chatterji 1966; Gómez and Espadaler 1997; Narbona 2002). E. esula can break dormancy after a 3-month period of after-ripening treatment (Best et al. 1980), and E. caducifolia, E. characias, and E. nicaensis, which are not native to Korea, do not exhibit dormancy. However, none of these studies have clearly revealed the morphology and development of the embryo. Therefore, detailed research is needed to determine the characteristics of non-dormancy and PD.

Accordingly, in this study, we aimed to obtain basic data for the development of new ornamental plants by identifying optimal germination conditions and classifying dormancy types for E. jolkinii seeds.

\section{Materials and methods \\ Plant material}

The E. jolkinii seeds used in this experiment were collected on June 14, 2018, in Seongsan-eup, Seogwipo-si,

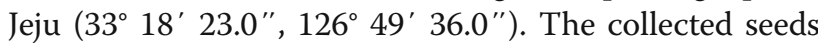
were dried at room temperature (approximately $25^{\circ} \mathrm{C}$ ) for 2 weeks in the laboratory and then used in experiments.

\section{Morphological characteristics of seeds}

To observe the morphology of the seeds, 20 seeds were randomly selected. The seeds were cut in half with a double-edged razor (stainless blade; Dorco, Seoul, Korea). The sections were photographed at 50-60x magnification using a Dino-Life Edge Digital Microscope (AM 3111 Dino-Lite Premier; AnMo Electronics Co., Taiwan), and the secession, internal and external shapes of the seeds, and germination process were observed.

\section{Water uptake test}

To investigate whether seeds showed PY, the water uptake rate was checked in three replicates of 30 seeds. Seeds were placed in plastic Petri dishes $(90 \mathrm{~mm} \times 10$ $\mathrm{mm}$ ) on top of two filter papers (Whatman No.1; GE Healthcare, Buckinghamshire, UK) moistened with distilled water at room temperature. Seeds were weighed after $0,3,6,9,12,24,48,72$, and $96 \mathrm{~h}$ of incubation. Percent water uptake was calculated as $\% W_{\mathrm{s}}=\left(\left[W_{\mathrm{h}}-\right.\right.$ $\left.\left.W_{\mathrm{i}}\right] / W_{\mathrm{i}}\right) \times 100$, where $W_{\mathrm{s}}$ is the increase in mass of the seed, $W_{\mathrm{h}}$ is the seed mass after a given interval of imbibition, and $W_{\mathrm{i}}$ is the initial seed mass at $0 \mathrm{~h}$.

\section{Temperature treatments}

Seeds were soaked in a solution of $1000 \mathrm{mg} / \mathrm{L}$ benomyl (Dongbu Benomyl; Farm Hannong, Seoul, Korea) for 1 h. After sterilization, the samples were washed with distilled water five times. Seeds were placed in plastic Petri dishes $(90 \mathrm{~mm} \times 10 \mathrm{~mm})$ on top of two filter papers (Whatman No.1; GE Healthcare) moistened with distilled water. To determine the optimum temperature for germination, seeds were incubated at $5,15,20$ and $25^{\circ} \mathrm{C}$ with light $(16 \mathrm{~h}$, cool white fluorescent lamp, approximately $25 \mu \mathrm{mol} / \mathrm{m}^{2} / \mathrm{s}$ ) or darkness in a constant temperature growth chamber (Multi-Room Incubator; WiseCube, Wonju, Korea). 


\section{$\mathrm{GA}_{3}$ treatments}

To promote germination, seeds were soaked in $\mathrm{GA}_{3}$ solutions of different concentrations $(0,10,100$, and 1000 $\mathrm{mg} / \mathrm{L}$ ) for $24 \mathrm{~h}$ at room temperature. Then, seeds were incubated at $15{ }^{\circ} \mathrm{C}$ and $25{ }^{\circ} \mathrm{C}$ under light conditions of $16 \mathrm{~h}$ light $/ 8 \mathrm{~h}$ dark. All treatments were conducted in triplicates with 30 seeds. Germination was checked at day 3 of the experiment. In growth chambers, the photosynthetic photon flux was approximately $25 \mu \mathrm{mol} / \mathrm{m}^{2} / \mathrm{s}$ during the light period, and a 16-h light/8-h dark photoperiod was used. Sterile water was periodically administered to keep the filter paper moist.

\section{Cold stratification treatments}

Sterilized seeds were treated for $0,4,8$, and 12 weeks at $4{ }^{\circ} \mathrm{C}$ and then incubated at $25{ }^{\circ} \mathrm{C}$. The experiment was performed in three repetitions of 30 seeds, and germination was measured at 1 -week intervals.

\section{After-ripening treatments}

The harvested seeds were dried and stored at room temperature for 0,3 , and 6 weeks. At the end of the treatment period, the seeds were sterilized and incubated at $25{ }^{\circ} \mathrm{C}$. The experiment was performed in three repetitions of 30 seeds, and germination was measured at 1week intervals.

\section{Germination investigation}

Germination was defined as the point at which radicles emerged at least $1 \mathrm{~mm}$ beyond the seed coat. Radicle emergence was checked every 3 days. After the final germination observation, poor-quality seeds were excluded from calculation of the germination percentage. The final germination was measured after 16 weeks of seed incubation. The germination characteristics, final germination percentage (FGP), day of germination, mean germination time (MGT) and days to $50 \%$ germination $\left(T_{50}\right)$ in days were calculated, as follows:

$$
\mathrm{FGP}=N_{\mathrm{g}} / N_{\mathrm{t}} \times 100
$$

where $N_{\mathrm{g}}$ is the number of final germinated seeds and $N_{\mathrm{t}}$ is the total number of seeds tested (Al-Mudaris 1998; Gharineh et al. 2004).

$$
\left.T_{50}=T_{\mathrm{i}}+\left[(N+1) / 2-N_{\mathrm{i}}\right) /\left(N_{\mathrm{j}}-N_{\mathrm{i}}\right)\right] \times(T \mathrm{j}-T \mathrm{i})
$$

where $N$ is the final number of seeds germinating, and $N_{\mathrm{i}}$ and $N_{\mathrm{j}}$ are the total numbers of seeds germinated by adjacent counts at times $T_{\mathrm{i}}$ and $T_{\mathrm{j}}$ (Coolbear et al. 1984).

$$
\mathrm{MGT}=\Sigma\left(N_{\mathrm{i}} \times T_{\mathrm{i}}\right) / N
$$

where $N_{\mathrm{i}}$ is the number of seeds germinated, $T_{\mathrm{i}}$ is the number of days from the start of the experiment, $N$ is the total number of germinated seeds at the end of the experiment (Naylor 1981).

\section{Data analysis}

Data were subjected to statistical analysis using SAS 9.4 software (SAS Inst. Inc., Cary, NC. USA). Statistical evaluation was conducted using analysis of variance, and significant data were analyzed further using Tukey's honestly significant difference test $(p \leq 0.05)$.

\section{Results}

Morphological characteristics of seeds

E. jolkinii seeds are surrounded by a hard pericarp with bumps (KBIS 2019). The seeds were dark brown and globose or spherical (Fig. 1A). The surface appeared smooth, but had a mesh structure (areolate) (KNA 2017). The collected seeds were $2.12-2.85 \mathrm{~mm}$ in length and $2.10-2.35 \mathrm{~mm}$ in width, with an average of 2.18 $\mathrm{mm}$. The weight of 100 seeds was approximately 473 $\mathrm{mg}$, and the percentage of sound seeds was approximately 66\%. After cutting the seeds, no endosperm vigor was observed in some of the seeds (Fig. 1D).

\section{Water uptake rate}

The weight of the seeds increased by $21 \%$ compared to the initial dry weight after $6 \mathrm{~h}$ of water absorption and by $39 \%$ after 24 h of water absorption (Fig. 2). After showing a $50 \%$ increase in water uptake, the seeds were saturated and did not increase further in weight after $72 \mathrm{~h}$.

\section{Temperature control of seed germination}

The FGPs at $5,15,20$, and $25{ }^{\circ} \mathrm{C}$ were $51.7 \%, 83.5 \%$, $2.6 \%$, and $0.0 \%$, respectively (Fig. 3 ). No seeds germinated under the four temperatures for four weeks. Less than $5 \%$ of the seeds germinated at $20{ }^{\circ} \mathrm{C}$ and $25{ }^{\circ} \mathrm{C}$. At $5{ }^{\circ} \mathrm{C}$ and $15^{\circ} \mathrm{C}$, germination started after 47.3 and 39.0 days, respectively (Table 1 ). The mean germination times at $5^{\circ} \mathrm{C}$ and $15{ }^{\circ} \mathrm{C}$ were 53.8 and 82.3 days, respectively. The FGP was higher at $15{ }^{\circ} \mathrm{C}$, but the germination progression was faster at $5{ }^{\circ} \mathrm{C}$. In addition, $T_{50}$ values were 48.7 and 85.0 days at 5 and $15^{\circ} \mathrm{C}$, respectively.

\section{Effects of $\mathrm{GA}_{3}$ treatment on seed germination}

$\mathrm{GA}_{3}$ effectively breaks seed dormancy, promotes embryo development, and enhances germination (Finch-Savage 2006; Baskin and Baskin 2014; Cho and Lee 2017). GA treatment affected the germination of $E$. jolkinii seeds at $15{ }^{\circ} \mathrm{C}$ and $25^{\circ} \mathrm{C}$; in particular, the germination was promoted effectively at $15{ }^{\circ} \mathrm{C}$. Following treatments with 0 , 10,100 , or $1000 \mathrm{mg} / \mathrm{L}$ of $\mathrm{GA}_{3}$, the germination percentages were $83.5 \%, 91.7 \%, 79.1 \%$, and $83.4 \%$, respectively, at $15{ }^{\circ} \mathrm{C}$ and $0 \%, 6.9 \%, 13.2 \%$, and $27.3 \%$, respectively, at $25{ }^{\circ} \mathrm{C}$ (Fig. 4). There were significant differences in the day of germination according to $\mathrm{GA}_{3}$ concentration 


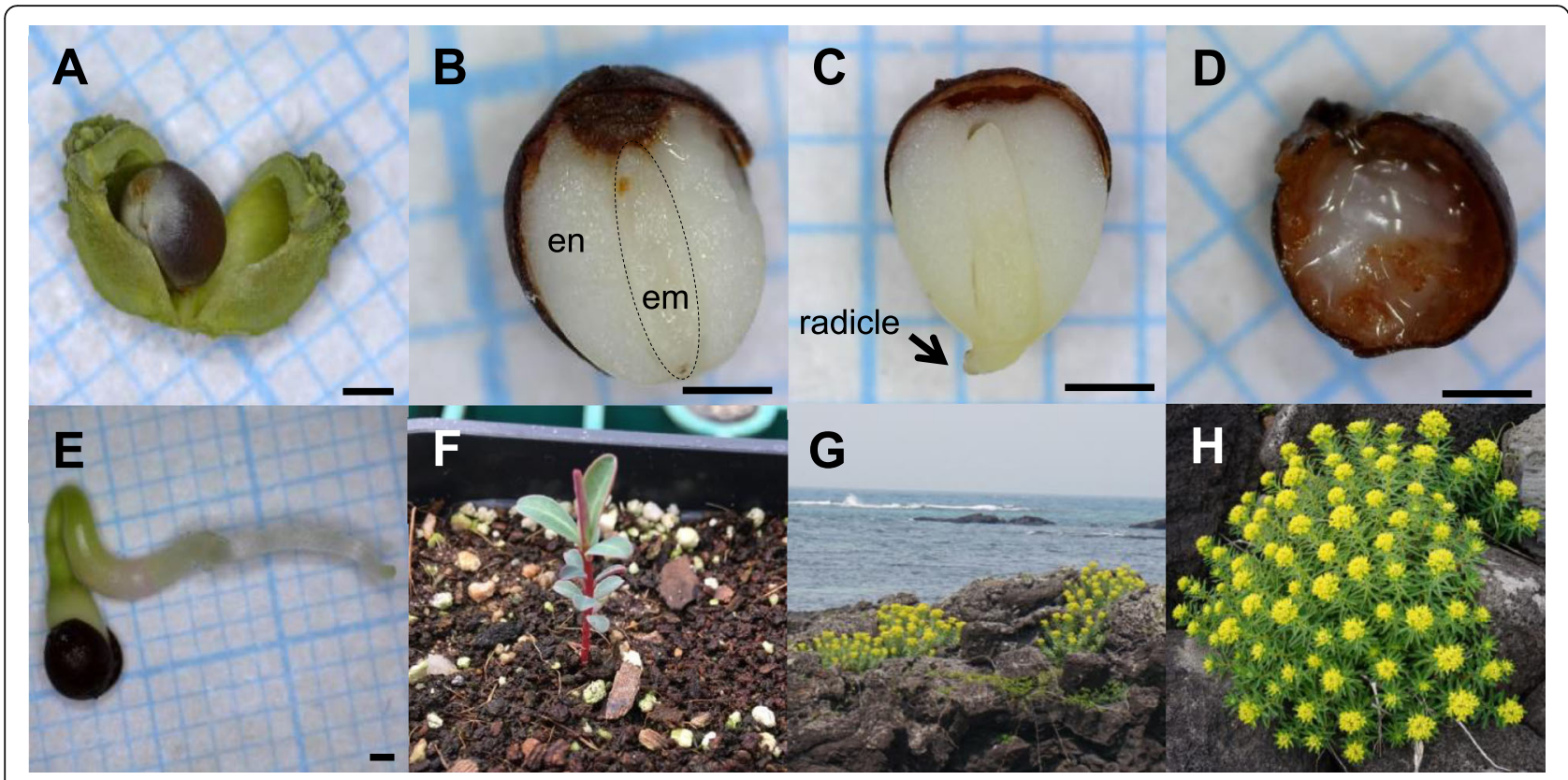

Fig. 1 Germination process of Euphorbia jolkinii Boiss. seeds. A A fruit and a seed. B Inner morphology. C A radicle. D A festered seed. E, F Seedling emergence. $\mathbf{G}$, $\mathbf{H}$ Flowering of $E$. jolkinii in a native habitat. en, endosperm; em, embryo. Scale bars = $1 \mathrm{~mm}$

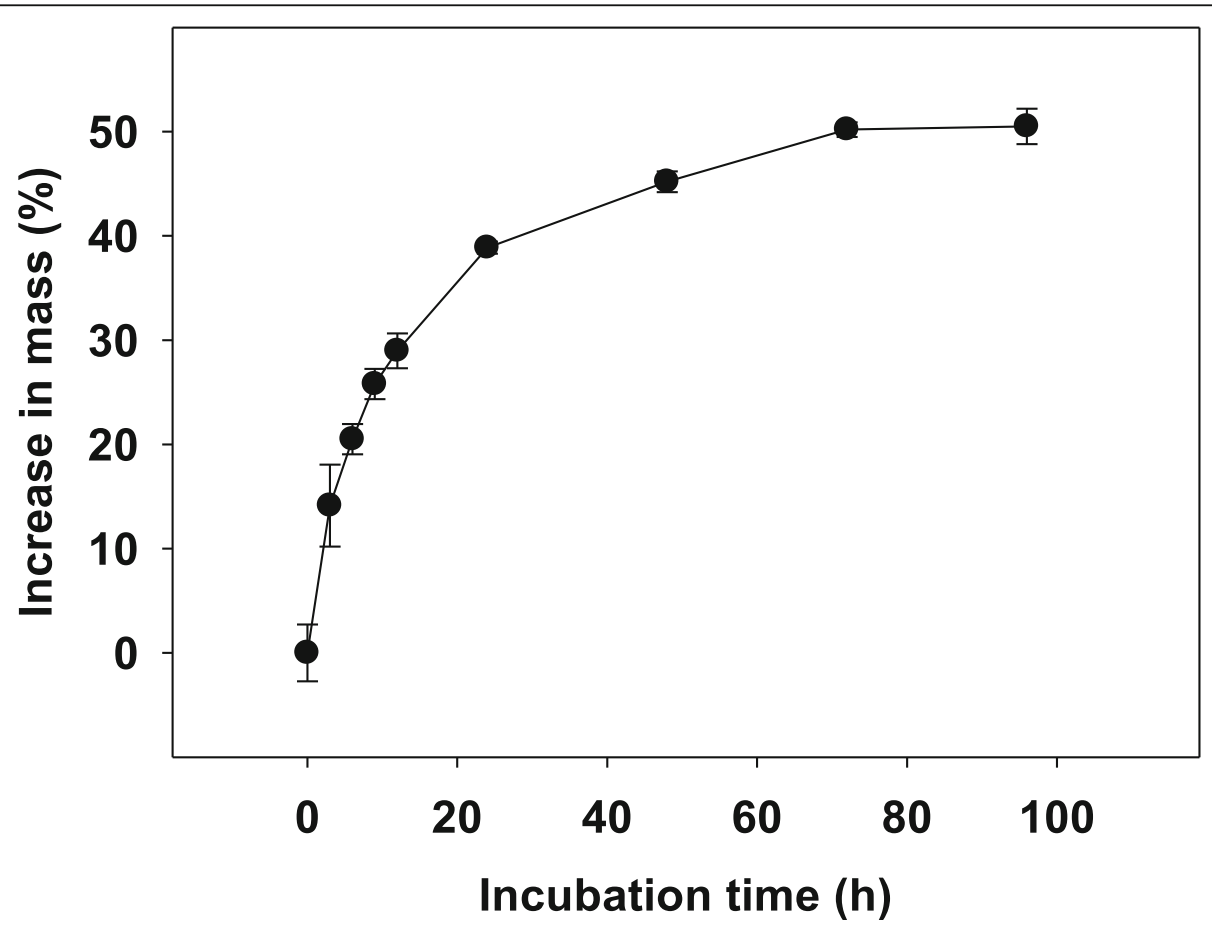

Fig. 2 Water uptake by seeds of Euphorbia jolkinii Boiss. as represented by an increase in mass. Seeds were incubated at room temperature for 96 h. Error bars indicate means \pm standard errors of three replicates of 30 seeds 


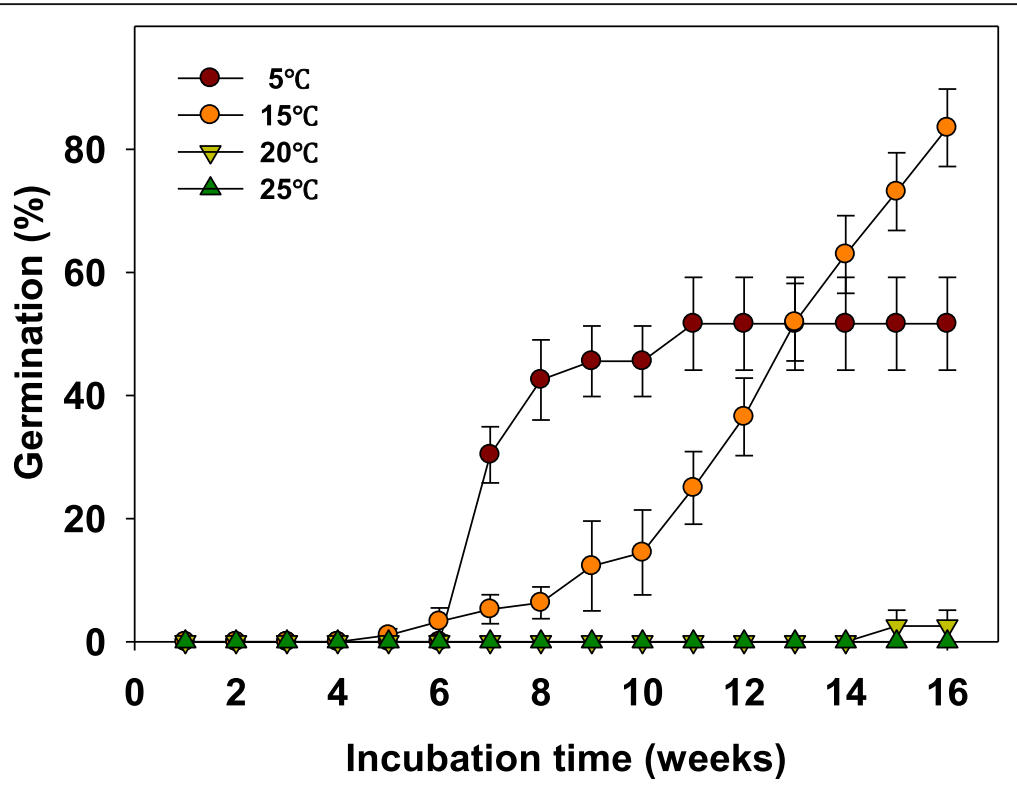

Fig. 3 Germination of Euphorbia jolkinii Boiss. seeds as affected by different temperature treatments. Error bars indicate means \pm standard errors of three replicates

(Table 2). At $15{ }^{\circ} \mathrm{C}$, the $\mathrm{GA}_{3}$ control started to germinate 39 days after the start of the experiment, whereas seeds treated with 100 and $1000 \mathrm{mg} / \mathrm{L} \mathrm{GA}_{3}$ started germination on days 13 and 7 , respectively. The mean times to germination after $0,10,100$, and $1000 \mathrm{mg} / \mathrm{L} \mathrm{GA} 3$ treatment were $82.3,84.7,34.8$ days, and 34.8 days, respectively, and the $T_{50}$ values were $85.0,95.0,47.7$, and 41.3 days, respectively (Table 2).

\section{Cold stratification treatments}

To assess the dormancy of E. jolkinii the germination percentage was observed for 9 weeks after cold stratification treatment for 4, 8, and 12 weeks. However, the germination percentage was less than $10 \%$ irrespective of the treatment duration.

\section{After-ripening treatments}

Germination was observed for 17 weeks after 3 and 6 months of after-ripening treatment at room temperature; however, the seeds did not germinate.

\section{Discussion}

The seeds were divided into basal, peripheral, and axile, according to the shape of the embryo (Martin 1946). In the basal type, the embryo does not exceed half the size of the seed and is located at the lower end. The peripheral type has a large embryo and is curved along the seed coat. In the axile type, the embryo varies and is located in the center of the seed (Song et al. 2019b). E. jolkinii seeds were axile, with the embryo located along the center of the seed (Fig. 1B). Seeds of plants native to the temperate regions are often separated from the parent without developing enough embryos, and seeds with such immature embryos are MD- or MPD-type seeds with a ratio of $0.5 \%$ or less. We confirmed that the length of the embryo in E. jolkinii seeds accounted for approximately $80-90 \%$ of the length of the seed, and the radicles protruded without any difference in the length of the embryo just before germination (Fig. 1C). Therefore, there was no MD in E. jolkinii seeds.

If germination does not occur because of the impermeability of the seed coat or pericarp, the seed is classified as showing PY (Baskin et al. 2000). If the water

Table 1 Effect of temperatures on the germination of Euphorbia jolkinii seeds

\begin{tabular}{llll}
\hline Temperature $\left({ }^{\circ} \mathrm{C}\right)$ & Days to germination & Mean times to germination & $\boldsymbol{T}_{\mathbf{5 0}}$ \\
\hline 5 & $47.3 \pm 1.3 \mathrm{~b}^{\mathrm{z}}$ & $53.8 \pm 1.8 \mathrm{~b}$ & $48.7 \pm 1.3 \mathrm{~b}$ \\
15 & $39.0 \pm 4.0 \mathrm{~b}$ & $82.3 \pm 2.9 \mathrm{a}$ & $85.0 \pm 3.0 \mathrm{a}$ \\
20 & $102.0 \pm 0.0 \mathrm{a}$ & - & - \\
25 & - & - & - \\
$P$-value & 0.0012 & 0.0011 & 0.0004 \\
\hline
\end{tabular}

${ }^{\mathrm{Z}}$ The different letters are significantly different $(p \leq 0.05)$ using Tukey's HSD test $(n=3)$ 


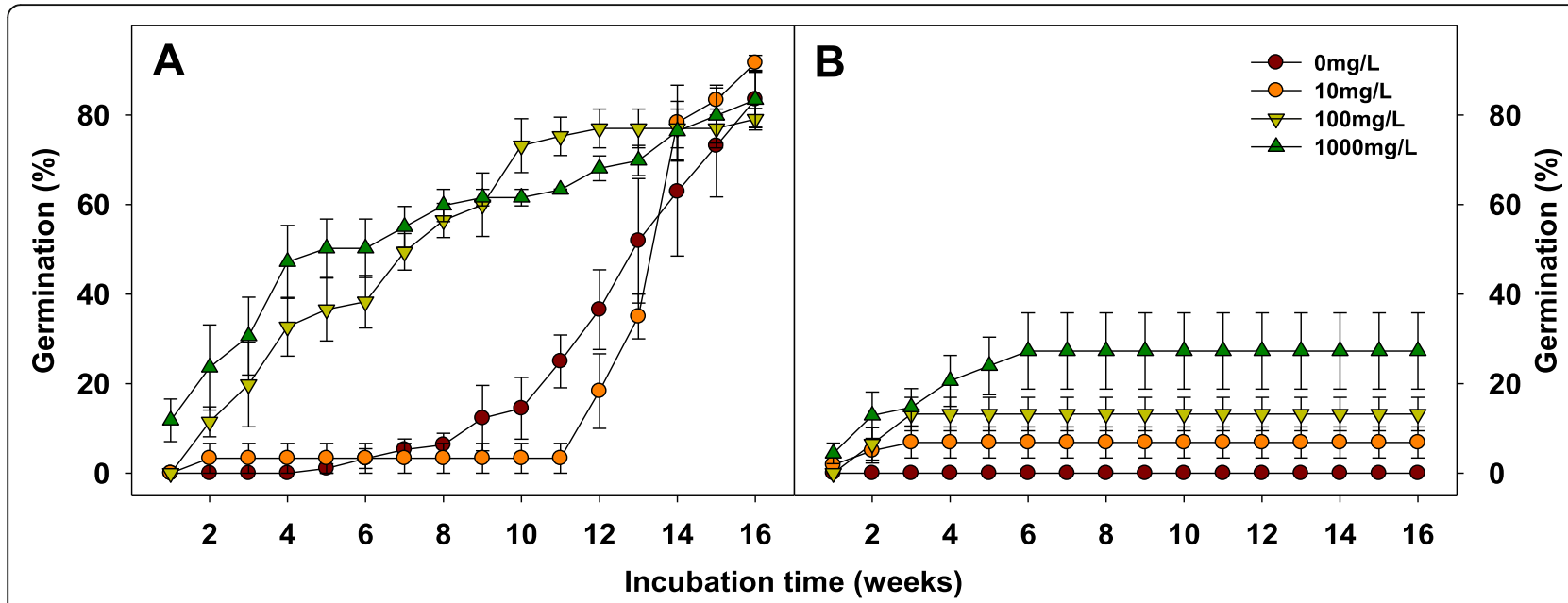

Fig. 4 Germination of Euphorbia jolkinii Boiss. seeds as affected by $\mathrm{GA}_{3}$ treatments. A $15^{\circ} \mathrm{C}$. B $25^{\circ} \mathrm{C}$. Error bars indicate means \pm standard errors of three replicates

uptake rate is more than $20 \%$ within $24 \mathrm{~h}$, the seed is judged to have water permeability (Baskin and Baskin 2003). Therefore, we found that there was no PY in $E$. jolkinii seeds, which had increased water absorption within $6 \mathrm{~h}$.

E. jolkinii had the highest germination percentage at $15{ }^{\circ} \mathrm{C}$. In comparison, E. boetica had a germination percentage of $73 \%$ at $17 / 21{ }^{\circ} \mathrm{C}$ (night/day, $13 \mathrm{~h} / 11 \mathrm{~h}$ ) and a $T_{50}$ of 7.4 days, and E. heterophylla had a germination percentage of about $80 \%$ at $25{ }^{\circ} \mathrm{C}$ and $30{ }^{\circ} \mathrm{C}$ (Cecilia and Jarbas 2000; Narbona et al. 2007). E. boetica grows in lowland pine forests or acidic soils (Benedí et al. 1997), and E. heterophylla grows as weeds in tropical and subtropical America (Hutchinson and Dalziel 1958; Wilson 1981). Different plants have different germination conditions, and even similar plants may show major differences in the germination characteristics when their native habitats differ at the national level (Baskin et al. 1989). Thus, we confirmed that the ideal environmental conditions for the germination of E. jolkinii, which is distributed only along the southern coast of Korea, were different from other species of the genus Euphorbia.

In non-deep PD, dormancy of seeds can be broken by various treatments, including 1-2 months of cold stratification treatment, after-ripening, and GA treatment. In intermediate PD, dormancy breaking through GA treatment is limited to some species, and it is possible to break dormancy through cold stratification treatment for 2-3 months (Geneve 2003; Baskin and Baskin 2004). In addition, it is possible to partially satisfy the low-temperature requirement for breaking dormancy through dry storage such as post-aging. In deep PD, the dormancy of seeds cannot be broken by GA treatment, but it is possible to break dormancy through 3-4 months of low-temperature or high-temperature wet treatment (Geneve 2003; Baskin and Baskin 2004). In this study, we showed that $\mathrm{GA}_{3}$ treatment could effectively improve the germination percentages of E. jolkinii seeds. The germination percentage was $79.1-83.4 \%$ at 100 and $1000 \mathrm{mg} / \mathrm{L}$, but there were no significant differences between these two concentrations. In addition, the day of germination, mean time to germination, and $T_{50}$ were shortened in the presence of 100 and $1000 \mathrm{mg} / \mathrm{L}$ $\mathrm{GA}_{3}$. Indeed, at these concentrations, the day to germination was 3-5 times earlier, the mean time to germination was shortened 2 times, and the $T_{50}$ was shortened by $2.0-2.3$ times compared with the control. Therefore, $\mathrm{GA}_{3}$ treatment improved the germination percentage

Table 2 Effect of $\mathrm{GA}_{3}$ concentrations on the germination of Euphorbia jolkinii seeds at $15^{\circ} \mathrm{C}$

\begin{tabular}{llll}
\hline $\mathbf{G A}_{\mathbf{3}}$ concentration $\mathbf{( m g / L )}$ & Days to germination & Mean times to germination & $\boldsymbol{T}_{\mathbf{5 0}}$ \\
\hline 0 & $39.0 \pm 4.0 \mathrm{~b}^{\mathrm{z}}$ & $82.3 \pm 2.9 \mathrm{a}$ & $85.0 \pm 3.0 \mathrm{a}$ \\
10 & $83.5 \pm 1.5 \mathrm{a}$ & $84.7 \pm 2.4 \mathrm{a}$ & $95.0 \pm 0.0 \mathrm{a}$ \\
100 & $13.0 \pm 1.0 \mathrm{c}$ & $34.8 \pm 2.8 \mathrm{~b}$ & $47.7 \pm 6.2 \mathrm{~b}$ \\
1000 & $7.0 \pm 0.0 \mathrm{c}$ & $34.8 \pm 9.1 \mathrm{~b}$ & $41.3 \pm 8.4 \mathrm{~b}$ \\
$P$-value & 0.0001 & 0.0004 & 0.0011 \\
\hline
\end{tabular}

${ }^{2}$ The different letters are significantly different $(p \leq 0.05)$ using Tukey's HSD test $(n=3)$ 
and shortened the mean time to germination, confirming that the seeds showed non-deep PD.

Among native plants in Korea, gibberellin treatment has been shown to improves or promotes seed germination. Germination percentages of Primula modesta var. hannasanensis T.Yamaz. were $95.0 \%$ and $95.5 \%$ at $\mathrm{GA}_{3}$ concentrations of 200 and $500 \mathrm{mg} / \mathrm{L}$, respectively, which were $56.0-69.0 \%$ higher than those of the control treatment (Cho and Lee 2017). Additionally, the germination percentage $(72.5 \%)$ of Tiarella polyphylla D. Don was improved by $\mathrm{GA}_{3}$ treatment at a concentration of 1000 $\mathrm{mg} / \mathrm{L}$ compared with the control treatment (33.3\%) (Choi et al., 2018). Moreover, the germination percentages of Veronica kiusiana var. diamantiaca (Nakai) T. Yamaz. were enhanced by $\mathrm{GA}_{3}$ treatment to $71.3 \%$, $87.2 \%$, and $91.7 \%$ at $\mathrm{GA}_{3}$ concentrations of 50,100 , and $1000 \mathrm{mg} / \mathrm{L}$, respectively, compared with that of the control (44.7\%) (Song et al. 2019b). Zanthoxylum piperitum (Kim et al. 1997), Exochorda serratifolia (Lee et al. 2006), Pinus pumila (Lim et al. 2015), Lychnis wilfordii (Regel) Maxim (Ryu et al. 2017), and many other species have also been shown to have improved germination percentages following gibberellin treatment, suggesting that this treatment breaks the PD of seeds. Accordingly, these findings showed that the concentration and time of gibberellin treatment were critical factors for improving germination percentages.

\section{Conclusion}

Wild native species have a wide distribution range, and it is not easy to establish an appropriate environment for seed germination. E. jolkinii Boiss. seeds require a longer time to germinate than other species in the same genus Euphorbia. In this study, we confirmed that these seeds showed no MD or PY, as demonstrated by embryo observation and water permeability. When germination was observed at various temperatures, we found that the optimum temperature for germination was $15{ }^{\circ} \mathrm{C}$, although the mean germination time at $15{ }^{\circ} \mathrm{C}$ was very late $(82.3$ days), and PD was confirmed. Additionally, the days to germination, mean time to germination, and $T_{50}$ were shortened following $\mathrm{GA}_{3}$ treatment at concentrations of 100 and $1000 \mathrm{mg} / \mathrm{L}$, thus classifying $E$. jolkinii seeds as showing non-deep PD. Overall, we confirmed that the germination of $E$. jolkinii seeds was improved at temperatures below $15^{\circ} \mathrm{C}$. In addition, cold stratification and after-ripening, $\mathrm{GA}_{3}$ individual treatments were not effective for germination. However, treatment with $\mathrm{GA}_{3}$ at $15^{\circ} \mathrm{C}$ reduced the mean germination time. Scientific conclusions on these environmental conditions and dormancy will be useful for establishing a mass production system for commercial use and ecological management.

\section{Abbreviations}

PD: Physiological dormancy; MD: Morphological dormancy;

MPD: Morphophysiological dormancy; PY: Physical dormancy; FGP: Final germination percentage; $T_{50}$ : Days to $50 \%$ germination; MGT: Mean germination time

\section{Acknowledgements}

Not applicable.

\section{Authors' contributions}

$\mathrm{OHJ}$ and SUS carried out the study, analyzed the data, and wrote the manuscript. LSY conceived the study design, analyzed the data, and reviewed the manuscript. KSY collected and analyzed the data. JMJ participated in the study and reviewed and edited the manuscript. All authors read and approved the final manuscript.

\section{Funding}

This study was funded by the project "Development of Year-round Cultivation and Flowering Control Technique for Native Wild Flowers Commercialization and its Diversification of Utilization (KNA1-2-33, 17-8)" funded by the Korea National Arboretum.

\section{Availability of data and materials}

The datasets generated during and/or analyzed during the current study are available from the corresponding author on reasonable request.

\section{Declarations}

Ethics approval and consent to participate

Not applicable.

Consent for publication

Not applicable.

\section{Competing interests}

The authors declare that they have no competing interests.

\section{Author details}

${ }^{1}$ Division of Plant Resources, Korea National Arboretum, Yangpyeong 12519, Korea. ${ }^{2}$ Seed Viability Research Team, Baekdudaegan National Arboretum, Bongwa 36209, Korea. ${ }^{3}$ Division of Horticulture \& Medicinal Plant, Andong National University, Andong 36729, Korea.

Received: 7 September 2021 Accepted: 30 September 2021

Published online: 19 October 2021

\section{References}

Adams CA, Baskin JM, Baskin CC. Trait stasis versus adaptation in disjunct relict species: evolutionary changes in seed dormancy-breaking and germination requirements in a subclade of Aristolochia subgenus Siphisia (Piperales). Seed Sci Res. 2005a;15(2):161-73. https://doi.org/10.1079/SSR2005207.

Adams CA, Baskin JM, Baskin CC. Comparative morphology of seeds of four closely related species of Aristolochia subgenus Siphisia (Aristolochiaceae, Piperales). Bot J Linnean Soc. 2005b;148(4):433-6. https://doi.org/10.1111/j.1 095-8339.2005.00402.x.

Al-Mudaris M. Notes on various parameters recording the speed of seed germination. Tropenlandwirt. 1998;99:147-54.

Bae KH. Medicinal plants in Korea. Seoul; Kyohaksa. 2000.

Baskin CC, Baskin JM. Seeds: ecology, biogeography, and evolution of dormancy and germination. San Diago: Academic Press; 1998.

Baskin CC, Baskin JM. When breaking seed dormancy is a problem: try a movealong experiment. Nativ Plant J. 2003;4(1):17-21. https://doi.org/10.3368/ npj.4.1.17.

Baskin CC, Baskin JM. Underdeveloped embryos in dwarf seeds and implications for assignment to dormancy class. Seed Sci Res. 2005;15(4):357-60. https:// doi.org/10.1079/SSR2005224.

Baskin CC, Baskin JM. Seeds: ecology, biogeography, evolution of dormancy and germination. 2nd ed. San Diego: Elsevier; 2014.

Baskin JM, Baskin CC. A classification system for seed dormancy. Seed Sci Res. 2004;14(1):1-16. https://doi.org/10.1079/SSR2003150. 
Baskin JM, Baskin CC, Li X. Taxonomy, anatomy and evolution of physical dormancy in seeds. Plant Spec Biol. 2000;15(2):139-52. https://doi.org/10.104 6/j.1442-1984.2000.00034.x.

Baskin JM, Baskin CC, Spooner DM. Role of temperature, light and date seeds were exhumed from soil on germination of four wetland perennials. Aquat Bot. 1989;35(3-4):387-94. https://doi.org/10.1016/0304-3770(89)90009-0.

Benedí C, Molero J, Simón J, Vicens J. Euphorbia. In: Castroviejo S, Aedo C, Benedí C, Laínz MR, Muñoz-Garmendia F, Nieto-Feliner G, Paiva J, editors. Flora Iberca, vol. 7. Madrid: Real Jardín Botánico de Madrid-CSIC; 1997. p. 210-85.

Best KF, Bowes GG, Thomas AG, Maw MG. The biology of Canadian weeds. 39. Euphorbia esula L. Can J Plant Sci. 1980;60(2):651-63. https://doi.org/10.4141/ cjps80-092.

Cecilia NKS, Jarbas FG. Seed reserve composition and mobilization during germination and initial seedling development of euphorbia geterophylla. Rev Bras Fisiol Veg. 2000;12(3):226-46. https://doi.org/10.1590/S0103-31312 000000300006

Chen SY, Tsai YH, Baskin CC, Baskin JM, Chien CT. Seed dormancy and germination of the three tropical medicinal species Gomphandra luzoniensis (Stemonuraceae), Nothapodytes nimmoniana (Icacinaceae) and Goniothalamus amuyon (Annonaceae). Seed Sci Res. 2015;25(01):57-63. https://doi.org/10.1017/S0960258514000385.

Cho JS, Lee CH. Dormancy and germination characteristics of alpine modest primrose (Primula modesta var. hannasanensis T.Yamaz.) seeds. Korean J Plant Res. 2017:30:372-7.

Choi H, Lee SY, Rhie YH, Lee JH, Kim SY, Lee KC. Seed dormancy type and germination characteristics in Tiarella polyphylla D. Don native to Korea. Korean J Plant Res. 2018:31:363-71.

Coolbear P, Francis A, Grierson D. The effect of low temperature pre-sowing treatment under the germination performance and membrane integrity of artificially aged tomato seeds. J Exp Bot. 1984;35:1609-17.

Euphorbia Planetary Biodiversity Inventory (PBI) Project. 2012. http://www. euphorbiaceae.org/index.html.

Fenner M, Thompson K. The ecology of seeds. NY: Cambridge University Press; 2005. https://doi.org/10.1017/CBO9780511614101.

Finch-Savage WE, Leubner-Metzger G. Seed dormancy and the control of germination. New Phytol. 2006;71(3):501-23. https://doi.org/10.1111/j.14698137.2006.01787.x.

Geneve RL. Impact of temperature on seed dormancy. Hortscience. 2003;38(3): 336-41. https://doi.org/10.21273/HORTSCI.38.3.336.

Gharineh MH, Bakhshandeh A, Ghasemi-Golezani K. Vigor and seed germination of wheat cultivar in Khuzestan environmental condition. Sci J Agric. 2004;27: $65-76$.

Gómez C, Espadaler X. Manipulación por hormigas de Semillas de Euphorbia characias (Euphorbiaceae) dentro del hormiguero. Sci Gerund. 1997;23:53-61.

Hutchinson J, Dalziel JM. Flora of west tropical Africa, Vol 1 (ii) (2nd edition, revised by Keay RWJ, 1973). London: Crown Agents for Overseas Governments and Administrations; 1958. p. 297-828.

Kim JY, Lee JA, Yoon WJ, Oh DJ, Jung YH, Lee WJ, et al. Antioxidative and antimicrobial activities of euphorbia jolkinii extracts. Korean J Food Sci Technol. 2006;38:699-706.

Kim MJ, Kim SY, Hyun KH, Kim DS, Kim SY, Hyun CG. Effects of Rumex axetosella, Sonchus oleraceus and euphorbia jolkinii extracts on melanin synthesis in melanoma cells. Korean Soc Biotechnol Bioeng J. 2017:32:187-92.

Kim SJ, Shin JH, Kim KJ, Park SD, Choi BS, Kim KU. Effect of GA $A_{3}$, kinetin and physical treatment on the seed germination of Zanthoxylum piperitum a.P. DC. Korean J Med Crop Sci. 1997;5:43-8.

Korea Biodiversity Information System (KBIS). 2019. http://www.nature.go.kr/kbi/ plant/pilbk/selectPlantPilbkDtl.do

Korea National Arboretum. Seed atlas of Korea. Seoul: Sumeunki Publishing Co.; 2017.

Korean Plant Names Index (KPNI). 2019. http://www.nature.go.kr/kpni/index.do

Lee HD, Kim SD, Kim HH, Lee JW, Kim JH, Lee CH, Lee CH. Effects of storage method, growth regulator, and inorganic salt on the seed germination of Eaochorda serratifolia S. Moore. Korean J Hortic Sci Technol. 2006;24:90-4.

Lim HI, Kim GN, Jang KH, Park WG. Effect of wet cold and gibberellin treatments on germination of dwarf stone pine seeds. Korean J Plant Res. 2015:28(2): 253-8. https://doi.org/10.7732/kjpr.2015.28.2.253.

Martin AC. The comparative internal morphology of seeds. Am Midl Nat. 1946; 36(3):513-660. https://doi.org/10.2307/2421457.

Narbona E. Estrategias reproductivas de dos especies perennes de euphorbia. Ph. D thesis. Sevilla: Universidad de; 2002.
Narbona E, Arista M, Ortiz PL. Seed germination ecology of the perennial euphorbia boetica, an endemic spurge of the southern Iberian Peninsula. Ann Bot Fennici. 2007:44:276-82.

Naylor REL. An evaluation of various germination indices for predicting differences in seed vigour in Italian ryegrass. Seed Sci Technol. 1981;9:593600.

Nikolaeva MG. Factors controlling the seed dormancy pattern. In: Khan AA, editor. The physiology and biochemistry of seed dormancy and germination. Amsterdam: North-Holland; 1977. p. 51-74.

Oh HJ, Shin US, Lee JS, Kim SY, Lee SY. Evaluation of postharvest cut flower characteristics of a new ornamental crop known as euphorbia jolkinii Boiss. Flower Res J. 2018;26(3):132-41. https://doi.org/10.11623/frj.2018.26.3.07.

Park KR. Euphorbiaceae. In: the genera of vascular plants of Korea. Flora of Korea editorial committee. Seoul: Academy Publishing Co; 2007.

Park SH, Kim JA, Hua XG, Lee CG, Choi JY. Isolation of 5a-reductase inhibitors from euphorbia jolkinii. Korean J Pharmacogn. 2005;36:9-16.

Ryu SH, Rhie YH, Lee SH, Ko CH, Lee JH, Lee KC. Effect of after-ripening, cold stratification, and $\mathrm{GA}_{3}$ treatment on Lychnis wilfordii (regel) maxim seed germination. Korean J Hortic Sci Technol. 2017;35:525-33.

Sen DN, Chatterji UN. Eco-physiological observations of euphorbia caducifolia Haines. Sci Cult. 1966;32:317-9.

Shin US, Lee JS, Oh HJ, Kim SY, Lee SY. Population distribution and growth environment of euphorbia jolkinii Boiss. In Jeju Island, Korea. Flower Res J. 2018a;26(3):109-16. https://doi.org/10.11623/frj.2018.26.3.04.

Shin US, Oh HJ, Lee JS, Min SY, Kim SY, Lee SY. Vegetative growth responses of euphorbia jolkinii Boiss. As affected by pot size and nutrients treatment Hortic Sci Technol. 2018b;36:189-90.

Shin US, Oh HJ, Min SY, Lee JS, Lee KC, Kim SY, et al. Effect of cutting date, photoperiod and plant growth regulators on rooting of euphorbia jolkinii Boiss. Stem cuttings. Hortic Sci Technol. 2017;35:189-90.

Song SJ, Park HB, Kim JS, Oh HJ, Kim SY, Jeong MJ, et al. Effect of holding solution on vase life of a new ornamental crop known as euphorbia jolkinii Boiss. Korean J Plant Res. 2019a;32:312-7.

Song SJ, Shin US, Oh HJ, Kim SY, Lee SY. Seed germination responses and interspecific variations to different incubation temperature in eight Veronica species native to Korea. Korean J Hortic Sci Technol. 2019b;37(1):20-31. https://doi.org/10.12972/kjhst.20190003.

Steinmann WW, Porter JM. Phylogenetic relationships in Euphorbieae (Euphorbiaceae) based on ITS and ndhF sequence data. Ann Mo Bot Gard. 2002;89:53-490.

Wilson AK. Euphorbia heterophylla: a review of distribution, importance and control. Trop Pest Manag. 1981;27(1):32-8. https://doi.org/10.1080/096708781 09414169.

\section{Publisher's Note}

Springer Nature remains neutral with regard to jurisdictional claims in published maps and institutional affiliations.

Ready to submit your research? Choose BMC and benefit from:

- fast, convenient online submission

- thorough peer review by experienced researchers in your field

- rapid publication on acceptance

- support for research data, including large and complex data types

- gold Open Access which fosters wider collaboration and increased citations

- maximum visibility for your research: over $100 \mathrm{M}$ website views per year

At $\mathrm{BMC}$, research is always in progress.

Learn more biomedcentral.com/submissions 